\title{
A conversation with Laurie Glimcher
}

$\mathbf{L}$ ologist who discovered the master transcription factors that direct immune cells to commit and activate. She's also discovered a key anabolic bonepathway and becomean expert on ER stress and lipoprotein production. Most recently, Glimcher (Figure 1) has discovered a critical signaling pathway in both tumor cells and host immune responses. All the while, she's acted as an academic leader, at Harvard School of Public Health, as dean of Weill Cornell Medical School, and she is about to take the reins of the Dana-Farber Cancer Institute as President and CEO.

JCI: What were you like as a kid?

Glimcher: My dad was a physicianscientist, and in many ways, I followed what he did. My mom was a homemaker. Both my parents were very early supporters of women; there was never any question that my two sisters and I were going to have independent careers. My sisters are my closest friends, but neither of them was particularly fond of hospitals or blood, but I was, so I used to go in with my father to work on weekends. $\mathrm{He}$ was chair of the Department of Orthopedic Surgery at Mass General and then the chair of Orthopedic Surgery at Children's Hospital and a biophysicist and a biochemist. And then I worked in his laboratory during high school and college.

JCI: Medicine imprinted very early?

Glimcher: It fit well with my interest in taking care of people. I used to grow flowers, and then I would take a dead flower and try to see if I could revive it. On the other hand, I was a little bit callous and I horrified my sisters, who are both tax lawyers now. One summer in Maine when I think I was about six years old, I dissected a frog on the front step of our little rental cottage and they were just horrified. I wanted to know what was inside of that frog.

JCI: What was your path towards medical school?

Glimcher: I went to Radcliffe and from thence on to Harvard Medical School. I wasn't really entirely sure what I wanted to do in college. I did some acting. I took probably more literature courses than I did sci- ence courses. I can't say that I had a thrillingly wonderful GPA. In fact, I would never get into medical schools nowadays. But I always liked thinking about the etiology of disease. I got accepted to a number of medical schools, and I was going to take a year

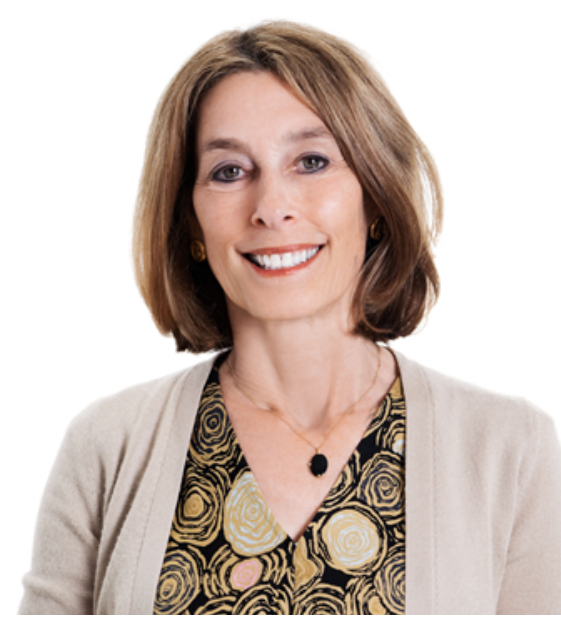

Figure 1. Laurie Glimcher in New York City, June 1, 2016. Image credit: Alexey Levchenko.

off because I started school a year early. But my father said to me, "You're probably never going to get into Harvard Medical School again, so this may not be the best time to take a year off." So I didn't.

When I arrived at medical school, my first reaction was, "Oh, my God. I don't belong here." There were so many brilliant people in my class. That first night I called my mother and said, "I can't do this. You have to come get me." She came and got me and she fed me some chicken soup and said, "Now you're going back and you're going to be fine."

JCI: And you were fine.

Glimcher: Yes, I was fine. I loved it; it became very clear those first few months that I was in the right place.

JCI: When did you start to think about immunology as your focus?

Glimcher: That was an aha moment. In the first year of medical school, you do various blocks. And one of those blocks was immunology. When I started hearing about the immune system, I absolutely fell in love with it. It was fascinating to think that you could have such an elegant system that can recognize self from non-self - I was captivated by autoimmune diseases in particular. I spent my fourth year in Harvey Cantor's lab, which was another eye-opening experience. I came to him saying I was fascinated by lupus and by autoimmune diseases. He said, "You have to understand the normal immune system before you can understand what goes awry."

I was stung by the research bug. I did like clinical medicine, but I wasn't sure how much of my time in the future I would spend seeing patients. I had decided to pursue a rheumatology clinical fellowship, but also went to the NIH to do some postdoctoral research first. My first husband, who was a transplant surgeon, was also interested in training. So he went to David Sachs's lab, I went to Bill Paul's laboratory, and it was just a fantastic three years.

JCI: You were there at a very heady time for immunology at the NIH. With Bill Paul, Ron Schwartz, Ethan Shevach, and then Mark Davis was cloning the TCR right next to you.

Glimcher: Mark Davis came up the same time I did. He too was a postdoc with Bill, and Steve Hedrick was a postdoc with Ron Schwartz. It was indeed a very heady time, and immunology was really premiere at the NIH. It was a very productive time for me because I was mentored, not only by Bill, but also by Ethan and by Al Singer.

Two months after I arrived, I gave birth to our daughter, Kalah, and I thought, "Well, I'll take some time off." But after I was at home for four or five days, I decided to go back to work. My mother was horrified. She said, "You have just had a C-section. You're supposed to stay home for three months." It was just the right thing for me. I was getting anxious and depressed, and I realized that this was not good for anybody, including my daughter.

JCI: What were you working on at NIH?

Glimcher: I started out with something that was relevant to autoimmunity and then segued into what I consider my major project, which was looking at the function of the MHC class II molecules. At that time, they hadn't been cloned. I was trying to produce 
a series of antigen-presenting cell lines that had mutations in their MHC class II molecules. I was told by everybody that our scheme was never going to work, but it did! That's where I learned that if you don't aim high, you are never going to make major contributions; you've got to be a risk taker.

We went back to Harvard three years later because my husband had to finish a surgical residency and I had to start my fellowship in rheumatology. But I just couldn't give up the laboratory because things were too exciting.

I had a 3-year-old and a 6-month-old. My husband was a surgical resident, so he was absolutely not around. I was trying to be a full-time clinical rheumatology fellow and to keep my lab going. Those may have been the most difficult years of my life.

JCI: You came back from the NIH with an R01.

Glimcher: I had an R01 because I decided to apply when I was a postdoc, when I was pregnant and about ready to deliver my older son. Harvard had to make me an instructor to keep the funding. So I came back as a faculty member even though I was a fellow, and I set up this little teeny lab with a couple of technicians to continue to work on the series of cell lines that I had generated that had MHC class II mutations. But I also decided I couldn't miss out on the molecular biology revolution, as the first MHC gene had been isolated. I did an informal minisabbatical with Jon Seidman and learned the technology and then hired a postdoctoral fellow to pursue structure function relationships.

This morphed into a fascination with how genes are regulated. That is when I decided that we should figure out how MHC class II genes are controlled. We looked to see what the defects were in patients who had bare lymphocyte syndrome. That also was fun for a while, but then I got a little restless and became interested in how $\mathrm{T}$ cells differentiate.

That is probably what I'm best known for: identifying the transcription factors that specify lineage commitment in T lymphocytes. Two postdocs, I-Cheng Ho and Suzanne Szabo, took on the isolation of key transcription factors that control type 1 and type 2 immunity. We pulled up what turned out to be T-bet and others, among which was c-maf, which controls IL-4. With Suzanne, I decided to focus on Th1 cells, which hadn't been much studied.
JCI: Everyone had been focusing on type 2.

Glimcher: Indeed, the focus was on type 2 and IL-4, and we had done a lot of promoter bashing in the IL-4 promoter, as had others, and there'd been a lot of promoter bashing for IL-2, which was at that point thought to be a Th1-specific cytokine, which it turned out not to be. We decided to do a yeast one-hybrid screen, which everybody thought was crazy because that had been done with multimerized sequences, and I thought that we really needed to do it with the whole IL-2 promoter.

We piloted it by using c-maf as a proof of principle, putting in the IL-4 promoter and then seeing if we could pick up c-maf, and we did. We picked up a factor that we named T-box expressed in T cells (T-bet). It took us a while to figure out what it did because everybody at that point was doing transient transfections. And this damn protein did not transactivate the IL-2 gene; it repressed it, and why? Just at that point, the technology to do retroviral gene transduction of primary cells emerged, and Suzanne came running into the office a couple weeks later and said, "You're not going to believe this but I've transduced primary T cells, and they're pouring out IFN- $\gamma$.

JCI: Was that your moment for champagne?

Glimcher: I didn't believe it at first. She had to repeat it a few times before I believed it. It turned out that T-bet was better than we thought and that it had really key functions in almost every immune cell, both in the adaptive and innate immune systems.

JCI: How did you first come across the bone anabolic pathway of Schnurri-3?

Glimcher: There have been a lot of serendipitous events in my scientific career. And you can choose to ignore a phenotype or to pursue it, and maybe I'm just easily distracted. We were actually looking for T-bet. A postdoc was subtracting Th2 cells from Th1 cells, looking for the factor that was critical to Th1 cells. He pulled up a protein that was then called KRC, thought to control VDJ recombination in the thymus, but it was really expressed heavily in Th1 cells.

We knocked it out and could not find an immune phenotype. We looked everywhere. I asked if my students had looked at every single organ, including the thymus, lymph nodes, and bone marrow. The graduate student said he was having trou- ble extracting the marrow from the bones because they seemed to be "occluded." I asked them to go to my dad's lab to take an $\mathrm{x}$-ray. After rolling their eyes, they decided to humor me. They came running back because the mice had unbelievably high bone mass and the bones looked normal.

You can create high bone mass with fluoride or other things, but that bone is biochemically and biophysically not good bone. It's not lamellar bone; it's woven or brittle bone. This bone looked good on x-ray. Clearly, I had skeletal biology in my genes. Together with my dad, we began to explore how this factor worked, what it did, and how could we harness it for therapeutic purposes. We are still working on Schnurri-3.

JCI: You served on the 2005 Larry Summers Task Force for Women in Science and Engineering. Where do things stand right now, both at Harvard and elsewhere for women in science?

Glimcher: I'm disappointed at the rate of progress for women in science and medicine. If you had asked me 30 years ago where women would be, I would have said, "We'll be running half the places. We're going to reach equality with men." That has not happened. There are still very few women in senior leadership roles, and that's true at all institutions around the country. We just haven't done well enough.

One of the things that I've always cared a lot about is mentoring - both men and women. But I have a special place in my heart for female scientists because I know how hard it is. I know how hard it is to raise a family, have a spouse who's incredibly busy, and pay enough attention to your kids.

JCI: I've often quoted you saying, "I've got a brain and a uterus and I use them both."

Glimcher: It is an excellent quote. But it's from Patricia Schroeder, the former congresswoman from Colorado. You have to put your money where your mouth is when it comes to mentoring women, and that is what I am trying to do.

JCI: If you had to do it all over again, what is the alternate career that you fantasize about, if it's not a scientist or a doctor?

Glimcher: There isn't one. I love the career I've chosen. I can't imagine, honestly, doing anything else that would bring me as much joy as doing this.

\section{Ushma S. Neill}

